\title{
Efficacy of Human Immunoglobulin and Penicillin $G$ in Treatment of Experimental Group B Streptococcal Infection
}

\author{
KWANG SIK KIM \\ Division of Infectious Diseases, Department of Pediatrics, Childrens Hospital of Los Angeles and The University \\ of Southern California School of Medicine, Los Angeles, California 90027
}

\begin{abstract}
In an effort to develop more effective therapy for neonatal group B streptococcal infections, penicillin $\mathbf{G}$ and human immune serum globulin (ISG), alone and in combination, were evaluated for their therapeutic efficacy against experimental group B streptococcal bacteremia and meningitis in newborn rats. Infected rats received either penicillin $\mathrm{G}(200 \mathrm{mg} / \mathrm{kg} / \mathrm{day})$, ISG $(2 \mathrm{~g} / \mathrm{kg})$ or penicillin $\mathrm{G}$ $(200 \mathrm{mg} / \mathrm{kg} / \mathrm{day})+$ varying doses of ISG $(0.25$ to $2 \mathrm{~g} / \mathrm{kg})$. All animals receiving ISG alone died; otherwise, mortality rates did not differ significantly (17-30\%). Therapy with penicillin $G$ alone and in combination with ISG was equally effective in completely eradicating group B streptococcal from blood and cerebrospinal fluid. However, combinations of penicillin G and ISG were significantly more beneficial than penicillin $\mathbf{G}$ alone, as shown by a significantly lower incidence of bacteremia at the end of 1 day of therapy and by greater opsonophagocytic activity in sera of animals receiving penicillin $G+$ ISG. These findings indicate that administration of ISG in conjunction with penicillin $\mathbf{G}$ rapidly clears bacteria from blood, suggesting that ISG may be a useful adjunct to antimicrobial therapy of neonatal group B streptococcal disease. (Pediatr Res 21: 289 $292,1987)$
\end{abstract}

Abbreviations

CFU, colony forming unit

CSF, cerebrospinal fluid

ELISA, enzyme-linked immunosorbent assay

GBS, group B streptococcus

ISG, immune serum globulin

PMNs, polymorphonuclear leukocytes

Since the GBS was recognized as a major cause of serious neonatal infection, penicillin $\mathrm{G}$ has been the mainstay of therapy for these infections. However, despite consistent sensitivity of GBS to penicillin, the clinical response to appropriate therapy is often poor. For this reason, several investigators have examined the potential use of other therapeutic modalities (e.g. leukocytes, immunoglobulins) (1-3).

Several lines of evidence suggest that type-specific antibody plays a critical role in protecting against GBS disease, both in

Received July 22, 1986; accepted October 27, 1986.

Supported in part by Public Health Service Research Grant RO1-AI 19454 from the National Institutes of Health.

Correspondence and requests for reprints to Kwang Sik Kim, M.D., Division of Infectious Diseases, Childrens Hospital of Los Angeles, 4650 Sunset Boulevard, Los Angeles, CA 90027. humans and in experimental animals (4-8). Recently, with the introduction of human immunoglobulin prepared for intravenous use (9-12), immunotherapy in conjunction with antimicrobial therapy has been suggested for the treatment of neonatal GBS infections.

The purpose of the present study was to evaluate the in vivo efficacy of human immunoglobulin alone and in combination with penicillin $G$ in the treatment of experimental type III GBS bacteremia and meningitis. As shown previously (13), a human immunoglobulin prepared by $\mathrm{pH} 4$ treatment was more active in vitro and in vivo against a type III GBS strain than a reduced and alkylated preparation, and therefore the former was used for this study.

\section{MATERIALS AND METHODS}

Organism. A type III GBS strain (K79) isolated from the CSF of a newborn infant with meningitis was used in this study. This strain was sensitive to penicillin $G$ with the minimal inhibitory and minimal bactericidal concentrations of 0.06 and $0.06 \mu \mathrm{g} / \mathrm{ml}$ (14).

ISG. A lyophilized preparation of human ISG (lot 2850) was obtained from Cutter Laboratories, Berkeley, CA. It is free of mercury-containing thimerosol preservative and prepared by treatment of Cohn fraction II with $\mathrm{pH} 4$. When reconstituted in $10 \mathrm{ml}$ sterile water, the solution contains $10 \%$ protein, of which at least $90 \%$ is IgG. The content of type III GBS antibody of human IgG class was $8.4 \mu \mathrm{g} / \mathrm{ml}$ as measured by ELISA (15).

In vivo studies. Outbred, pathogen-free, Sprague-Dawley pregnant rats with timed conception were purchased from Charles River Breeding Laboratories, Wilmington, MA and gave birth in our vivarium 5 to 7 days after arrival. The methods to induce GBS bacteremia and meningitis in 5-day-old rats and to monitor the responses of such infections to treatment with antibiotics in terms of bacterial clearance in blood and CSF have been described previously $(14,16,17)$.

A total of 122 animals from 10 litters was used. At 5 days of age, all members of each litter were inoculated subcutaneously with $1 \times 10^{5} \mathrm{CFU}$ of strain K79. Eighteen hours after inoculation and daily thereafter for 4 days, $0.1 \mathrm{ml}$ blood and $0.01 \mathrm{ml} \mathrm{CSF}$ were obtained for quantitative cultures. Immediately after the first blood and CSF specimens were obtained, each litter was randomly divided into six treatment groups: group 1 , penicillin G; group2, ISG $2 \mathrm{~g} / \mathrm{kg}$; group 3 , penicillin $\mathrm{G}+\mathrm{ISG} 2 \mathrm{~g} / \mathrm{kg}$; group 4 , penicillin $\mathrm{G}+\mathrm{ISG} 1 \mathrm{~g} / \mathrm{kg}$; group 5 , penicillin $\mathrm{G}+\mathrm{ISG} 0.5 \mathrm{~g} /$ $\mathrm{kg}$; and group 6, penicillin G + ISG $0.25 \mathrm{~g} / \mathrm{kg}$. Penicillin $\mathrm{G}$ was given subcutaneously twice daily $(0900$ and $1900 \mathrm{~h})$ at a dose of $100 \mathrm{mg} / \mathrm{kg}$ and ISG was given intraperitoneally as a single dose. The dose of penicillin $G$ was chosen based on results of our previous studies to produce serum and CSF concentrations at $1-$ $2 \mathrm{~h}$ within the therapeutic range (14). Therapeutic efficacy was 
determined by comparing rates of bacterial clearance from blood and CSF as well as mortality rates among the six groups.

All surviving animals had one blood and CSF sample drawn at $1-2 \mathrm{~h}$ after subcutaneous administration of penicillin $\mathrm{G}$ on therapy day 3 to determine bactericidal titers. Bactericidal titers were determined by a microtiter technique $(14,16)$ with a serial 2 -fold dilution of serum or CSF in Mueller-Hinton broth and an inoculum of strain K79 of approximately $5 \times 10^{5} \mathrm{CFU} / \mathrm{ml}$. The bactericidal titers in serum or CSF were defined as the highest dilution of serum or CSF that results in $>99.9 \%$ killing.

Opsonophagocytic assays. Serum samples were also assayed for opsonic activity by a microtiter plate modification of the method of Hirsch and Strauss (18). Neutrophils were isolated from Sprague-Dawley adult rats by dextran sedimentation followed by Ficoll-Hypaque density centrifugation (13). PMNs were washed and then adjusted to a concentration of $5 \times 10^{6} / \mathrm{ml}$. This PMN preparation was contaminated with erythrocytes but consistently yielded PMNs $>90 \%$ of the leukocytes. Neutrophils (approximately $2 \times 10^{5} \mathrm{PMNs} / 40 \mu \mathrm{l}$ ) were added to roundbottom microtiter wells (Nunc, Roskilde, Denmark) along with $10 \mu \mathrm{l}$ washed logarithmic-phase strain K79 (approximately $2 \times$ $10^{5} \mathrm{CFU}$ ), $10 \mu \mathrm{l}$ pooled newborn rat serum (screened for absence of type III GBS antibody by ELISA) as a source of complement and $40 \mu \mathrm{l}$ serum that had been incubated at $37^{\circ} \mathrm{C}$ for $1 \mathrm{~h}$ in the presence of penicillinase $(10,000 \mathrm{U} / \mathrm{ml}$, Difco Laboratories, Detroit, MI) to inactivate any killing effect due to penicillin. Minimal essential medium with Earle's balanced salt solution (Gibco Laboratories, Santa Clara, CA) was used in washing and resuspension of PMNs and bacteria.

A final mixture contained a ratio of PMNs to bacteria of approximately $1: 1$. The microtiter plates were incubated at $37^{\circ}$ $\mathrm{C}$ with constant shaking (American Rotator V, American Dade, Miami, FL). Aliquots $(10 \mu \mathrm{l})$ were taken from each well at 0 and $1 \mathrm{~h}$, serially diluted 10 -fold in sterile distilled water, and plated on blood agar for determination of surviving CFUs. Results were expressed as the percentage of bacteria killed:100-(CFU at $1 \mathrm{~h} /$ $\mathrm{CFU}$ at $0 \mathrm{~h} \times 100$ ).

Statistical methods. The $\chi^{2}$ test (with the Yates' correction for small samples) was used to compare the incidence of bacteremia and mortality and the Student's $t$ test to compare the magnitude of bacteremia and opsonic activity among groups of animals (19). $P$ values of $\leq 0.05$ were considered significant.

\section{RESULTS}

In vivo efficacy. GBS bacteremia was present in all $122(100 \%)$ animals and meningitis (positive CSF culture) developed in 53 (43\%) animals $18 \mathrm{~h}$ after infection and just before therapy (Table 1). At this time, the prevalence of meningitis and the bacterial counts in blood and CSF did not differ significantly in the animals assigned to the various treatment groups (Table 1).

Table 1 compares the overall mortality and bacterial clearance from blood and CSF among the six treatment groups. All animals receiving ISG alone died within 2 days of therapy. Otherwise, the mortality rates among the remaining five groups were not significantly different.

The bacterial clearance from blood of the six treatment groups was compared by determining bacterial counts of animals with positive blood cultures at 1,2 , and 3 days of completed therapy (Table 1). In every group, the number of animals available for

Table 1. Comparison of mortality and bacterial clearance in blood and CSF among the six groups of animals treated with penicillin $G, I S G$, or penicillin $G+$ varying doses of ISG

\begin{tabular}{|c|c|c|c|c|c|c|}
\hline \multirow[b]{2}{*}{ Therapy regimen* } & \multirow{2}{*}{$\begin{array}{c}\text { No. of } \\
\text { animals }\end{array}$} & \multirow{2}{*}{$\begin{array}{c}\text { Treatment } \\
\text { days }\end{array}$} & \multirow{2}{*}{$\begin{array}{l}\text { No. of } \\
\text { deaths }\end{array}$} & \multirow{2}{*}{$\begin{array}{c}\text { Overall } \\
\text { mortality } \\
(\%)\end{array}$} & \multicolumn{2}{|c|}{ Bacterial counts $\left(\log _{10} \mathrm{CFU} / \mathrm{ml}\right)$ in } \\
\hline & & & & & Blood & CSF \\
\hline \multirow[t]{4}{*}{ Penicillin G } & 22 & 0 & & & $5.69 \pm 1.15(22 / 22) \dagger$ & $3.37 \pm 2.12(11 / 11) \dagger$ \\
\hline & & 1 & 4 & & $2.46 \pm 1.27(7 / 18)$ & $7.87(1 / 9)$ \\
\hline & & 2 & 0 & & $1.35(1 / 18)$ & $4.95(1 / 9)$ \\
\hline & & 3 & 0 & $4(18)$ & $0(0 / 18)$ & $5.39(1 / 9)$ \\
\hline \multirow[t]{4}{*}{ ISG $2(\mathrm{~g} / \mathrm{kg})$} & 17 & 0 & & & $5.36 \pm 1.40(17 / 17)$ & $5.54 \pm 1.42(8 / 8)$ \\
\hline & & 1 & 13 & & $7.61 \pm 1.61(4 / 4)$ & NA \\
\hline & & 2 & 4 & & NA $\ddagger$ & NA \\
\hline & & 3 & 0 & $17(100)$ & $\mathrm{NA}$ & NA \\
\hline $\begin{array}{c}\text { Penicillin G } \\
+\end{array}$ & 23 & 0 & & & $5.70 \pm 1.46(23 / 23)$ & $5.22 \pm 2.61(10 / 10)$ \\
\hline \multirow{3}{*}{ ISG $2(\mathrm{~g} / \mathrm{kg})$} & & 1 & 6 & & $1.35(1 / 17)$ & $1.85(1 / 5)$ \\
\hline & & 2 & 1 & & $0(0 / 16)$ & $0(0 / 4)$ \\
\hline & & 3 & 0 & $7(30)$ & $0(0 / 16)$ & $0(0 / 4)$ \\
\hline $\begin{array}{c}\text { Penicillin G } \\
+\end{array}$ & 17 & 0 & & & $5.26 \pm 1.32(17 / 17)$ & $3.13 \pm 1.82(7 / 7)$ \\
\hline \multirow[t]{3}{*}{ ISG $1(\mathrm{~g} / \mathrm{kg})$} & & 1 & 3 & & $1.35(1 / 14)$ & $0(0 / 5)$ \\
\hline & & 2 & 0 & & $0(0 / 14)$ & $0(0 / 5)$ \\
\hline & & 3 & 0 & $3(17)$ & $0(0 / 14)$ & $0(0 / 5)$ \\
\hline $\begin{array}{c}\text { Penicillin G } \\
+\end{array}$ & 22 & 0 & & & $5.44 \pm 1.29(22 / 22)$ & $5.27 \pm 2.44(8 / 8)$ \\
\hline \multirow[t]{3}{*}{ ISG $0.5(\mathrm{~g} / \mathrm{kg})$} & & 1 & 4 & & $1.35(1 / 18)$ & $6.97(1 / 4)$ \\
\hline & & 2 & 0 & & $0(0 / 18)$ & $3.69(1 / 4)$ \\
\hline & & 3 & 0 & $4(18)$ & $0(0 / 18)$ & $1.85(1 / 4)$ \\
\hline $\begin{array}{c}\text { Penicillin } G \\
+\end{array}$ & 21 & 0 & & & $5.43 \pm 1.11(21 / 21)$ & $4.31 \pm 1.78(9 / 9)$ \\
\hline \multirow[t]{3}{*}{ ISG $0.25(\mathrm{~g} / \mathrm{kg})$} & & 1 & 4 & & $1.35 \pm 0.00(3 / 17)$ & $0(0 / 5)$ \\
\hline & & 2 & 1 & & $0(0 / 16)$ & $0(0 / 5)$ \\
\hline & & 3 & 0 & $5(24)$ & $0(0 / 16)$ & $0(0 / 5)$ \\
\hline
\end{tabular}

\footnotetext{
* Penicillin $\mathrm{G}$ was given subcutaneously at $100 \mathrm{mg} / \mathrm{kg}$ dosage, twice daily.
}

$\dagger$ Numbers in parentheses indicate the number of animals positive for culture after completion of treatment day/the number of animals positive for culture before therapy and available for subsequent determination of bacterial counts.

$\ddagger$ Not applicable (no survivors available). 
Table 2. Comparison of opsonic activity against a type III GBS of serum from the five treatment groups

\begin{tabular}{|c|c|c|}
\hline $\begin{array}{l}\text { Therapy regimen } \\
\text { (no. of specimens) }\end{array}$ & $\begin{array}{l}\text { No. of sera } \\
\text { with no } \\
\text { killing }\end{array}$ & $\begin{array}{c}\text { No. of sera } \\
\text { with } \\
\geq 80 \% \\
\text { killing }\end{array}$ \\
\hline $\begin{array}{l}\text { Penicillin } G(n=10) \\
\text { Penicillin } G\end{array}$ & 10 & 0 \\
\hline $\begin{array}{l}\stackrel{+}{\mathrm{ISG}} 2(\mathrm{~g} / \mathrm{kg})(n=12) \\
\text { Penicillin G }\end{array}$ & 0 & 11 \\
\hline $\begin{array}{l}\stackrel{+}{\operatorname{ISG} 1(\mathrm{~g} / \mathrm{kg})(n=9)} \\
\text { Penicillin G }\end{array}$ & 2 & 6 \\
\hline $\begin{array}{l}\stackrel{+}{\text { ISG } 0.5(\mathrm{~g} / \mathrm{kg})(n=10)} \\
\text { Penicillin G }\end{array}$ & 2 & 7 \\
\hline $\begin{array}{c}+ \\
\text { ISG } 0.25(\mathrm{~g} / \mathrm{kg})(n=10)\end{array}$ & 3 & 6 \\
\hline
\end{tabular}

these observations decreased with the deaths. Bacterial counts in blood increased in animals receiving ISG alone, while treatment with penicillin $G$ alone or in combination with ISG enhanced bacterial clearance from the blood of surviving animals. Overall, the incidence of bacteremia at the end of 1 day of treatment was significantly less in animals receiving penicillin $\mathrm{G}+$ ISG $(6 / 65$ or $9 \%)$ than in those receiving penicillin $G$ alone $(7 / 18$ or $39 \%$, $\chi^{2}=7.27, p<0.01$ ). These differences were particularly impressive for those groups of animals receiving penicillin $\mathrm{G}+\mathrm{ISG} \geq$ $0.5 \mathrm{~g} / \mathrm{kg}$. However, penicillin $\mathrm{G}$ alone and in combination with ISG were equally effective in completely eradicating GBS from the blood of surviving animals after 3 days of therapy.

After 1 day of treatment, 28 of the 53 animals with GBS meningitis before therapy were alive for repeated cisternal punctures. Again, both penicillin $\mathrm{G}$ and penicillin $\mathrm{G}+$ ISG effectively enhanced bacterial clearance from the CSF of surviving animals. Only one animal each in the penicillin $\mathrm{G}(1 / 9$ or $11 \%)$ and penicillin $\mathrm{G}+\mathrm{ISG} 0.5 \mathrm{~g} / \mathrm{kg}$ (1/4 or $25 \%)$ groups yielded positive CSF cultures after 3 days of therapy.

Bactericidal and opsonic activity. Bactericidal titers in serum and CSF obtained $1-2 \mathrm{~h}$ after subcutaneous administration of penicillin $G$ on therapy day 3 were $>512$ and $\leq 14 \pm 5$ (geometric mean \pm SEM of reciprocals of bactericidal titers), respectively, and these values did not differ significantly from those of animals that received penicillin $\mathrm{G}+$ varying doses of ISG. As shown previously, serum and CSF specimens from untreated healthy as well as infected animals did not kill strain K79.

Table 2 summarizes the opsonic activity of sera from five different treatment groups. All animals receiving ISG alone died before therapy day 3 and sera were not available. An incubation of sera in the presence of penicillinase at $37^{\circ} \mathrm{C}$ for $1 \mathrm{~h}$ completely abolished the killing activity of sera from the penicillin group. Nevertheless, almost all sera from the penicillin $+I S G 2 \mathrm{~g} / \mathrm{kg}$ group (11/12 or $92 \%$ ) exhibited efficient opsonic activity: $>80 \%$ killing of the original inoculum was observed at $1 \mathrm{~h}$ of incubation. In animals receiving penicillin $\mathrm{G}+$ ISG $1,0.5$, or $0.25 \mathrm{~g} / \mathrm{kg}$, most of the sera $(60-70 \%)$ also supported $>80 \%$ killing of the original inoculum.

\section{DISCUSSION}

Many previous investigators have suggested a beneficial therapeutic effect of combining human $\gamma$ globulin and antibiotics against infections caused by various gram-positive and gramnegative organisms (20-23). In addition, Shigeoka et al. (24) have shown that infants infected with GBS and transfused with whole blood containing specific opsonic antibody have improved survival when compared with infants receiving blood lacking antibody to the infecting strains. Because of the significant mortality and morbidity associated with neonatal GBS infections, more information is needed regarding combined chemotherapy and immunotherapy. The feasibility of this approach has been aided by the availability of ISG preparations modified for intravenous use because intravenous ISG preparations, compared with intramuscular ISG, produce immediate high blood levels of antibody and can be an advantageous adjunct. The availability of the newborn rat model of experimental GBS bacteremia and meningitis (25) has also been helpful. As shown previously (14, $16,17,25)$, this model has several important similarities to GBS infections in human newborns: age dependency, hematogenous infection of the meninges without requiring mechanical disruption of the blood-brain barrier, and high mortality. In addition, techniques developed for serial atraumatic collection of blood and CSF specimens enable us to use this experimental model to evaluate treatment efficacies not only by mortality rates, but also be rates of bacterial clearance from blood and CSF.

Our findings revealed that ISG alone was not efficacious in the treatment of established GBS infection, in contrast to those of our previous studies which showed that ISG was extremely effective in providing protection in the same newborn rat model against oral or subcutaneous challenge of the same type III GBS strain $(13,26)$. These findings are in agreement with those of other investigators $(27,28)$ who found that ISG did not protect newborn rats from lethal challenge with GBS when administration of ISG was delayed $12-15 \mathrm{~h}$ after bacterial inoculation. Also, in this study, penicillin $\mathrm{G}$ at the dose of $200 \mathrm{mg} / \mathrm{kg} / \mathrm{day}$ alone failed to ensure the successful therapy of GBS infection: $18 \%(4 /$ 22 ) of the animals died and $38 \%(7 / 18)$ still had bacteremia after 1 day of penicillin therapy. This limited value of penicillin $G$ was observed despite use of a highly penicillin-sensitive strain (minimal inhibitory and minimal bacteridical concentrations of 0.06 and $0.06 \mu \mathrm{g} / \mathrm{ml}$ ) to induce bacteremia and meningitis and also achievement of excellent bactericidal titers in serum and CSF against the infecting strain after administering penicillin $G$. Recently, we have shown that rates of bacterial clearance and mortality do not differ significantly even with use of much higher doses of penicillin $\mathrm{G}(800 \mathrm{mg} / \mathrm{kg} /$ day $)(29)$. The reasons for this limitation of penicillin therapy are not clear; one possibility may be that in some animals, GBS infections may have been advanced too far and thus not readily controlled by penicillin therapy. For example, when we compared the pretherapy bacterial counts in blood between animals that died within 1 day of therapy or remained bacteremic at the end of 1 day of therapy with animals that survived and were free of bacteremia at the end of 1 day of therapy, the former group had significantly higher bacterial counts in blood than the latter group $(6.43 \pm 0.60$ versus $4.75 \pm$ $\left.1.02 \log _{10} \mathrm{CFU} / \mathrm{ml}, p<0.001\right)$. Thus, the size of bacterial population at the beginning of therapy may have influenced the efficacy of penicillin therapy. Such an inoculum effect has also been well documented in vitro $(30,31)$.

When ISG was given to infected animals in conjunction with penicillin $G$, mortality rates did not differ significantly from those receiving penicillin $G$ alone. However, the incidence of bacteremia at the end of 1 day of treatment was significantly lower, particularly in animals receiving penicillin $G+$ ISG $\geq 0.5$ $\mathrm{g} / \mathrm{kg}$. The clinical significance of this finding is not clear. Since outcome from neonatal Escherichia coli meningitis has been shown to correlate directly with the duration of positive bacterial cultures in $\operatorname{CSF}(32,33)$, it is conceivable that delayed bacterial eradication may contribute to the significant morbidity associated with neonatal GBS infection. In addition, sera from animals that received penicillin G + ISG exhibited efficient opsonophagocytic activity ( $>80 \%$ killing of the initial inoculum) even after the removal of penicillin-mediated killing activity. These findings support the salutary effect of passively administered ISG in restoring the opsonic activity of infected hosts against GBS which may further improve the efficacy of penicillin therapy against neonatal GBS disease. Additional studies are needed to deter- 
mine whether the beneficial advantage of ISG can also be demonstrated against many other strains and serotypes of GBS.

Acknowledgments. The author thanks Dr. Bascom F. Anthony for measuring the type III group B streptococcal antibody, Jane Kang and Carol Wass for technical assistance, and Lourdes Cruz for typing the manuscript.

\section{REFERENCES}

1. Laurenti F, Ferro R, Isacchi G, Panero A, Savignoni PG, Malagnino F, Palermo D, Mandelli F, Bucci G 1981 Polymorphonuclear leukocyte transfusion for the treatment of sepsis in the newborn infant. J Pediatr 98:118-123

2. Christensen RD, Rothstein G, Anstall HB, Bybee B 1982 Granulocyte transfusions in neonates with bacterial infection, neutropenia, and depletion of mature marrow neutrophils. Pediatrics 70:1-6

3. Fischer GW, Weisman LB, Hemming VG, London WT, Hunter KW, Bosworth JM, Sever JL, Wilson SR, Curfman BL 1986 Intravenous immunoglobulin in neonatal group B streptococcal disease. Am J Med 76:117-123

4. Baker CJ, Kasper DL 1976 Correlation of maternal antibody deficiency with susceptibility to neonatal group B streptococcal infection. $\mathrm{N}$ Engl $\mathbf{J}$ Med 294:753-756

5. Hemming VG, Hall RP, Rhodes PG, Shigeoka AO, Hill HR 1976 Assessmen of group $B$ streptococcal opsonins in human and rabbit serum by neutrophil chemiluminescence. $J$ Clin Invest 58:1379-1387

6. Lancefield RC, McCarty M, Everly WN 1975 Multiple mouse-protective antibodies directed against group B streptococci. J Exp Med 142:165-179

7. Fischer GW, Hunter KW, Wilson SR 1982 Modified human immune serum globulin for intravenous administration: in vitro opsonic activity and in vivo protection against group B streptococcal disease in suckling rats. Acta Paediatr Scand 71:639-644

8. Shigeoka AO, Pincus SH, Rote NS, Hill HR 1984 Protective efficacy of hybridoma type-specific antibody against experimental infection with group B streptococcus. J Infect Dis 149:363-372

9. Ochs HD 1980 Intravenous immunoglobulin therapy of patients with primary immunodeficiency syndromes: efficacy and safety of a new modified immune globulin preparation. In: Alving BM, Finlayson JS (eds) Immunoglobulins: Characteristics and Uses of Intravenous Preparations. US Department of Health and Human Services, Food and Drug Administration, Bethesda, MD, DHHS Publication no. (FDA)-80-9005, pp 9-14

10. Pirofsky B, Anderson CJ, Bardana Jr EJ 1980 Therapeutic and detrimental effects of intravenous immunoglobulin therapy. In: Alving BM, Finlayson JS (eds) Immunoglobulins: Characteristics and Uses of Intravenous Preparations. US Department of Health and Human Services, Food and Drug Administration, Bethesda, MD, DHHS Publication no. (FDA)-80-9005, pp $15-22$

11. Barandun S, Morell A, Skvaril F 1980 Clinical experiences with immunoglobulin for intravenous use. In: Alving BM, Finlayson JS (eds) Immunoglobulins: Characteristics and Uses of Intravenous Preparations. US Department of Health and Human Services, Food and Drug Administration, Bethesda, MD, DHHS Publication no. (FDA)-80-9005, pp 31-35

12. Bjorkander J, Wadsworth C, Hanson LA 19851040 prophylactic infusions with an unmodified intravenous immunoglobulin product causing few sideeffects in patients with antibody deficiency syndromes. Infection 13:102110
13. Kim KS, Wass CA, Kang JH, Anthony BF 1986 Comparative functional activities against type III group B streptococcus of human immunoglobulin prepared for intravenous use by different methods. J Infect Dis 153:10921097

14. Kim KS, Bayer AS 1985 Efficacy of BMY-28142 in experimental bacteremia and meningitis caused by Escherichia coli and group B streptococci. Antimicrob Agents Chemother 28:51-54

15. Anthony BF, Concepcion NF, McGeary SA, Ward JI, Heiner DC, Shapshak $P$, Insel RA 1982 Immunospecificity and quantitation of an enzyme-linked immunosorbent assay for group B streptococcal antibody. J Clin Microbiol $16: 350-354$

16. Kim KS 1985 Efficacy of imipenem in experimental group B streptococcal bacteremia and meningitis. Chemotherapy 31:304-309

17. Kim KS 1986 Efficacy of cefmenoxime in experimental group B streptococcal bacteremia and meningitis. J Antimicrob Chemother 17:239-244

18. Hirsch JG, Strauss B 1964 Studies on heat-labile opsonin in rabbit serum. J Immunol 29:145-154

19. Colton T 1974 Statistics in Medicine. Little, Brown \& Co, Boston

20. Fisher MW 1957 Synergism between human gamma globulin and chloramphenicol in the treatment of experimental bacterial infections. Antibiot Chemother 7:315-321

21. Milligan RC, Rust J, Rosenthal SM 1957 Gammaglobulin factors protective against infections from pseudomonas and other organisms. Science 126:509_ 511

22. Waisbren BA 1957 The treatment of bacterial infections with the combination of antibiotics and gamma globulin. Antibiot Chemother 7:322-332

23. Sonea S, Borduas A, Frappier A 1958 Combined protective action of human gamma globulin and antibiotics when administered simultaneously in experimental staphylococcal infection. Rev Can Biol 17:110-115

24. Shigeoka AO, Hall RT, Hill HR 1978 Blood-transfusion in group-B streptococcal sepsis. Lancet 1:636-638

25. Ferrieri P, Burke B, Nelson J 1980 Production of bacteremia and meningitis in infant rats with group B streptococcal serotypes. Infect Immun 27:10231032

26. Kim KS, Dunn K, McGeary A, Stiehm ER 1984 Efficacy of orally administered immune serum globulin against type III group B streptococcal colonization and systemic disease in an infant rat model. Pediatr Res 18:1329-133

27. Santos JI, Shigeoka AO, Rote NS, Hill HR 1981 Protective efficacy of a modified immune serum globulin in experimental group B streptococcal infection. J Pediatr 99:873-879

28. Fischer GW, Wilson SR, Hunter KW 1982 Functional characteristics of a modified immunoglobulin preparation for intravenous administration. Summary of studies of opsonic and protective activity against group B streptococci. J Clin Immunol 2(suppl):31S-35S

29. Kim KS 1987 Effect of antimicrobial therapy on mortality and clearance of bacteria. In experimental group B Streptococcal infections. J Infect Dis (in press)

30. Feldman WE 1976 Concentrations of bacteria in cerebrospinal fluid of patients with bacterial meningitis. J Pediatr 88:549-552

31. McGeary SA, Kim KS, Ward JI 1983 Susceptibility of group B streptococcus to beta-lactam antibiotics. Drugs Exp Clin Res 9:693-696

32. McCracken Jr GH 1972 The rate of bacteriologic response to antimicrobial therapy in neonatal meningitis. Am J Dis Child 123:547-553

33. McCracken Jr GH, Glode MP, Sarff LD, Mize SG 1974 Relation between Escherichia coli $\mathrm{K} 1$ capsular polysaccharide antigen and clinical outcome in neonatal meningitis. Lancet 2:246-250 